\title{
Re-imagining Digital Technology in Education through Critical and Neo-materialist Insights
}

\author{
Magda Pischetola \\ magd@itu.dk \\ IT University of Copenhagen, Denmark
}

\begin{abstract}
Technological determinism, techno-solutionism and instrumental perspectives on technologies have populated educational research literature in the last decades, and even more since the pandemic crisis has started. This essay offers a critique about simplistic explanations of technology adoption in pedagogy by using insights from critical philosophy of technology and feminist new materialism. It rejects the assumption of teachers' resistance to change and proposes a frame to expand future imaginaries of education. In this sense, critical studies provide a focus on human activity as interconnected with social and situated knowledges/practices. The emphasis is on recursive relations that allow educational researchers and practitioners to take into account the considerable complexity of digital technologies pedagogical adoption. On the other hand, feminist new materialism brings about a new focus on relational ontology, which adds to the critical theoretical framework the agentic element. By overcoming a binary way of seeing technologies through utopias and dystopias, new materialist studies focus on ethics and responsibility. We argue that we need both a critical and neo-materialist view, in order to adopt technologies in education in meaningful, productive and creative ways. Building on small narratives and possible utopias can take us to re-design and re-interpret the future of educational technologies.
\end{abstract}

\section{Keywords:}

Critical theory; feminist new materialism; digital technologies; education; imaginaries. 


\section{Introduction}

In the last decades, educational research has broadly underlined the benefits of technologies for the enhancement of learning processes and outcomes. Most studies have shown a tendency to make technology appear neutral (Dusek, 2006), 'natural' (Oliver, 2011) and conceptually straightforward (Creanor and Walker, 2012). These approaches minimize the pedagogical aspects that are involved in the relationship between technologies and learning, such as the role of the teacher as a key agent of change (Priestley, 2011), the situated environment (Kocsev et al. 2009; Philip \& Garcia, 2013) and the value of both experience and improvisation in teaching (Howard \& Gigliotti, 2016; Silva et al. 2019). This has become an urgent matter in face of the worldwide accelerated introduction of online, blended and 'remote' education engendered by the Covid-19 pandemic (Williamson et al., 2020) as techno-solutionism seems a particularly appealing answer to global uncertainty (Milan, 2020; Teräs et al., 2020). In many cases, teaching online and other virtual formats have been considered the 'best answer' to the emergency, as they have assured continuity to classrooms and lectures through digital platforms (Ferdig et al., 2020). However, these choices hide massive impacts on inequity and inequality (Selwyn 2020), while generate new markets (Williamson 2019, 2020) and ignore decades of research about pedagogical practices (Hodges et al. 2020; Miranda and Pischetola 2020). What we see happening is new perspectives for future education being supported by commercial organisations and their networks, who propose "a radical 'reimagining' and prototyping of education systems" (Williamson \& Hogan, $2020,57)$. Will a post-pandemic school be online? Will university teaching be blended/hybrid/at a distance from now on?

In this paper, we argue that a critical-materialist approach to educational technologies is needed in order to develop counter-narratives (Selwyn et al., 2020) and expand the imagination about the future of education (Pischetola, 2021), beyond the interests of the private IT sector.

The paper starts by questioning the long-standing consolidated assumption of a causal relationship between digital technologies pedagogical adoption and innovation. First, we aim at dismantling the overspread idea of 'teachers' resistance' as a barrier for digital technologies adoption (Peixoto, 2015; Pischetola, 2019). In fact, we suggest that the argument concerning teachers' resistance is the result of both a technology-driven and a use-focused view, which have in common the basic assumption of the neutrality of technology, and efficiency as main driving principle. Critical studies have discussed profound and complex ethical issues that arise from such deterministic assumptions and have pointed out at distributed, rather than individual, responsibilities in shaping the future of education. It has been asked what values are embedded in a technological tool (Feenberg, 2003); whether we can trust technologies, especially Artificial Intelligence, in a sophisticated world like the educational one (Selwyn, 2019); and in whose interest are political decisions taken (Biesta, 2010; Williamson et al. 2020).

Starting from these grounds, we discuss how to support teachers in adopting digital tools and environments in ways that align with their values, and within a pedagogy of care (Puig de la Bellacasa, 2011). By drawing on neo-materialist feminism, we consider all kind of technology as agentic matter, ontologically related to human action (Haraway 1988; Barad, 2007). Our ambition is to reach an understanding of educational practices and processes through/with/about technologies that enable or disable 'human flourishing' (Ransom \& Gallagher, 2020). Ultimately, we defend the need to situate human relations at the core of learning processes and to adopt a pedagogy which gives value to affectivity and difference (Andrade \& Pischetola, 2016), with a focus on knowing as becoming (Barnett \& Bengsten 2017; Dall'Alba 2009; Fenwick \& Edwards, 2014). 


\section{Literature review}

The literature of the last two decades on the implementation of digital technologies in education has often focused on 'barriers' to pedagogical adoption. In a systematic review, Bingimlas (2009) divided the barriers found in research in two macro categories: school-level barriers and teacherlevel barriers. The first category includes the contextual obstacles, created by lack of time, lack of training, lack of access, and lack of technical support. The second category of studies comprises factors such as lack of teacher confidence, insufficient teacher competence, and 'resistance to change'. This last factor is explained in literature by negative teachers' attitude towards the use of digital technologies (Jamieson-Proctor et al., 2006; Korte \& Hüsing, 2007; Schoepp, 2005; Watson, 2006), or by teachers' beliefs, which can constitute an obstacle to technologies adoption (Balanskat et al., 2006; Tondeur et al., 2019).

With a different research perspective, some works aimed to investigate the protagonism of the teacher, considered as one of the most determining factors for the significant use of digital technologies in teaching and learning (Aldunate \& Nussbaum, 2013; Drent \& Meelissen, 2008; Sing \& Chan, 2014). These studies have highlighted the commitment made by the individual subject, who would be conditioned by the perception of responsibility towards the students' results or the search for personal satisfaction. More specifically, it has been stated the importance of the teacher giving up the role of catalyst of knowledge, to become a 'facilitator' of pedagogical processes, and reconfigure pedagogical classroom practices with a student-centred approach and the initiative to bypass the infrastructural limits (Goodwin et al., 2015). Much of the referred literature suggests that teachers' protagonism and active role would be synonymous with an 'entrepreneurial attitude' (Hitty, 2002; Seikkula-Leino et al. 2010; Shane \& Venkataraman, 2000) to develop skills and practices in line with the $21^{\text {st }}$ century. Therefore, the lack of such protagonism is also considered a form of resistance of the teacher to innovative uses of digital tools and environments in education.

Research by Becta (2004) shows that the process of adoption is slow, as it affects a shift from old practices to new ones, and some teachers reject digital technology for the fear of being substituted by it. Teachers who show a stronger resistance to change are those who see no benefits in the pedagogical use of technologies. In the same line of thought, Watson (2006), among others, claimed that integrating digital tools in teaching practice demands a change of mindset. This aspect is also underlined by recent international reports such as the Horizon Reports (Brown et al., 2020; Alexander et al., 2019) and Innovating Pedagogy (Ferguson et al., 2019; Kukulska-Hulme et al., 2020), as well as European research frameworks (Caena \& Redecker 2019; Frau-Meigs et al, 2017). Some authors have also stressed the important role of risk-taking attitudes and teachers' openness towards the new (Howard \& Gigliotti, 2016).

Despite recognising the need to consider innovation as related to a change of mindset (Pischetola, 2014), we present a critical reflection about the reasons why the assumption of 'rejection/ resistance', frequently mentioned in edtech studies, falls short in explaining unexpected outcomes of technology pedagogical adoption. In what follows, we argue that the idea of a teacher resistance to change is related to technological determinism, techno-solutionism and/or an instrumental view of digital technology.

\section{a. Technological Determinism}

As Lawrence and Tar (2018) point out, there is a large number of studies that have examined the relationship between characteristics of innovation and the digital technologies adoption in teaching. Most of these studies find evidence of the impact of teachers' positive attitude and experience for successful transformation in educational practices. A common assumption is that the failure of technology adoption in teaching is the result of teachers' resistance to change and innovation. We perceive in these studies an ideological vision that can be associated with technological 
determinism: digital technology, as a technical artefact, would be able to innovate the educational environment with its mere presence (Mangiatordi \& Pischetola, 2010).

Determinism presupposes a certain relationship between a specific cause - the presence of technology in a given social environment - and a predictable and predetermined effect (Oliver, 2011). Rogers' diffusion of innovations theory offers a good example of this assumption. Rogers (1995/2003) claims that the diffusion of a technological artefact can be typified as a communication process, that is, the way the artefact is perceived by a social system at a given historical time. Although not indicating the isolation of the 'communication' factor from other social elements, Rogers attributes to the communication process the power to generate the diffusion effect of innovations, which can be interpreted as determinism (Smith \& Marx, 1994). Rogers states that the adoption rate relates to innovation characteristics as perceived by an individual in a social system.

Other theories prior to the 1980s regarded technological change as an uncontrolled process of social and historical formation that developed autonomously following an internal and incomprehensible technical logic. The most radical deterministic theories, such as Jacques Ellul's (1964), emphasise the autonomy and power of technology. The more moderate ones consider some incursion of the context in the social control over the technology. All conceive technological innovation as the driving force of sociocultural change. Dafoe (2015) finds three elements which are common to all deterministic perspectives: (1) the prominence of the technique over human agency; (2) the autonomy of technology development in a delimited historical moment; (3) the absence of human consciousness regarding the social effects of technology. Peixoto (2015) highlights one more aspect: the predictability of technology development beyond cultural or political influence. Based on the supposed possibility of predicting the effects - positive or negative - that a technology will have on society, studies emerge that assume a prophetic position. They offer utopias and dystopias about the possibilities that a technology brings to society, as if the mode of use of the instrument would somehow be inscribed in the tool (Ferreira et al., 2017).

In this view, teachers' technical skills and competencies would be the crucial factor that allows digital technologies implementation in education and the consequent change in learning outcomes. Therefore, if the implementation encounters some obstacles, it is mainly because of an individual failure of the teacher, which is followed by the non-reconfiguration of his/her practices (Gomes et al. 2012). From this perspective, the very need to integrate digital technologies in the school environment (the reason 'why') is not questioned, as the focus is mostly on 'how' technology is inserted in education (Pischetola, 2019).

\section{b. Techno-solutionism}

Techno-solutionism is an evolution of utopian technological determinism, driven by a tendency to prioritise the tool rather than the social, cultural and political environment (Morozov, 2011).

Techno-solutionism has populated the political discourse in education of the last decades, and even more since the pandemic crisis. In fact, the idea of technological development as a solution to societal problems has grown parallel to neoliberal policies that understand learning as sets of skills that individuals need to acquire to enter the market (Jandrić \& Hayes 2020). We cannot avoid considering digital technologies as part of a network composed by different actors - civil society, edtech providers, corporate investors, among others - which bring business-related interests into play (Grimaldi \& Ball, 2019; Williamson \& Hogan 2020). As such, techno-solutionism would be closely related to the increasing process of 'neoliberalisation' (Peck \& Tickell 2002) of education. In fact, as noticed by Buckingham (2020), tech-monopolies like Apple are particularly able to target education through 'cyber-utopianism' regarding learning possibilities and schools' transformation. However, Morozov (2014) underlines that techno-solutionism can also derive from well-intentioned 
attempts to solve complex problems with simplistic solutions, with the idea that given the right information, machines can solve all kinds of problems.

As a long-established idea, we can see that historically computer technology has reinforced in men the expectation that technological innovation is synonymous of human progress (Postman, 1992). This perspective emerged in the 1950s, with the constitution of Artificial Intelligence as a new field of study. The basic assumption of AI is that human intelligence could in future (or can already?) be replicated and replaced by machines programmed to function, or think, in a similar way to humans. With a computational allegory, human intelligence has been compared to information processing (McCarthy, 1959) and regarded as measurable by the results achieved (Embretson, 2004; Kurzweil, 2006). Several authors warn that, based on these ideas, there is an implication of distrust in human judgment and subjectivity (Coeckelbergh, 2011; Smith, 2019). The metaphor of the 'human machine' and the 'brain-computer' is also increasingly present in education, reflected by linear learning processes that separate cognition, emotion and sensorimotor, which give special relevance to the cognitive capacity of humans (Bannell, 2019).

Current studies about educational technologies emphasise how each new technology is often considered an "isolated instigator of change" (Jandrić \& Hayes, 2020) to which human skills and abilities have to adapt. Policy discourse based on techno-solutionism continues to separate humans and machines in a simplified perspective on learning (Hayes, 2018; Pischetola, 2021), without taking into consideration the complexity of present and future societal developments (Peters et al., 2019).

By analysing the growing phenomenon of implementation of learning analytics in schools and higher education, Selwyn (2019) found seven categories of consequences, among which he mentions a general simplification of meanings (e.g. a reduced understanding of what is meant by 'education' or by 'decision-making processes), which mainly serve institutional interests, rather than providing individual benefits. As part of what he calls 'techno-idealism', the author shows concern about "a blind faith in 'data"' (Selwyn, 2019: 14), and the related limitation of individual choices and agency. What is at stake is learners' autonomy to make decisions for themselves, given massive surveillance processes and the spread of the idea that "learning and teaching can be objectively defined, measured, and modelled" (ibid.).

Milan (2020) argues that quantification and trust in data become even more seductive in times of uncertainty. She shows how during the COVID-19 pandemic, numbers are considered valuable because they are 'objective', they simplify access to knowledge and do not need to rely to the context. In a quest for quick answers, big data and predictive analytics are very easily transformed in "silver-bullet solutions" (Milan, 2020: 4) with prescriptive consequences. In fact, "although numbers per se do not claim neutrality, truth, or scientific authority, they contribute to create realities, communities, policies and public concern" (ibid.).

\section{c. Technological Instrumentalism}

In response to determinism/techno-solutionism, we find approaches that disqualify the existence of a positive or negative social impact of technologies. From this perspective, the effects do not depend on technology and its characteristics, but on the uses humans wish to make of it. Technology is perceived as a 'neutral' tool, which can be used for various purposes. This view takes in literature the name of instrumentalism. As Pischetola and Miranda (2019) report, in educational research we find countless examples of the instrumental view of technology. This is seen as a mere means of the teacher's willingness, as a support for pedagogical practice or as a support for teaching action. According to this perspective, the teacher decides to make a 'correct' use or a 'wrong' use of it, determining the 'goodness' or 'harm' for educational settings.

Despite a different point of view on technology than determinism, we can observe that the responsibility for implementing digital technologies in education rests, again, with the teacher. In 
fact, this interpretation ignores the importance of the historical, institutional, socioeconomic, and cultural context, and places all the attention on the subject. Ferreira and Lembgruber (2018) claim that the metaphor of technology as a 'tool' conceals the historical, political, and cultural aspects, and sees technology as well defined, interpreted, and represented. In other words, neutral. Thus, we realize the limits of the research focus on individual uses of technology and the risk of separating these uses from their contexts, losing their complex and socially constructed character (Peixoto, 2015; Pischetola, 2011). At the functional level, technologies are reduced to decontextualised devices and systems, which identify with their useful properties (Feenberg, 2004).

An attempt to include more factors of influence for technology adoption and integration in education comes from the Technology Acceptance Model (Davis, 1993). This theory postulates that two different constructs, Perceived Usefulness and Perceived Ease of Use, affect teachers' attitudes, beliefs and intentions towards acceptance or rejection of digital technologies. Even if this perspective takes into account organisational aspects, we find in many of the studies based on this approach a limitation in the understanding of digital tools and environment complexity. Technologies are seen as tools, and their uses are at the core of the discussion. Again, this model provides an instrumental view and fails in considering digital technologies as ways of organising knowledge, communication practices and modes of learning. As a result, the materiality of technology, the values embedded in its design, and the relationship between its features and the uses teachers make of it are aspects of the learning environment that are not considered relevant. Moreover, such an approach, as most academic studies in the field of educational technology, tends to focus on the 'potential' of educational technology, that is, how technologies could and should be used in education, rather than how they are actually being used (Selwyn, 2010).

Against this backdrop, a growing body of literature has recognised the need for further qualification of a critical approach to technology adoption in education (Dale et al., 2014; Heinsfeld \& Pischetola, 2019; Selwyn, 2017), beyond the evaluation of teacher's attitude and context barriers. These alternative perspectives are very valuable if we want to "move beyond failure" (Sancho-Gil et al. 2019) of edtech projects around the world and foster technology imagination in educational settings (Balsamo, 2011). In the following section, we suggest that such an alternative path can be pursued through critical and neo-materialist reflections on the future of technology in education.

\section{Developing a critical and neo-materialist thinking}

\section{a. Critical theory and the value of disruption}

In order to identify alternative ways of framing the relationship between digital technology and teaching, we firstly present the contribution of Frankfurt School critical theory to the field of philosophy of technology (Cuban, 2002; Feenberg, 2003). Drawing on Marx, critical theorists place human practices and activities in connection with socio-historical and technological modes of production. Their aim is not merely to describe the world, but rather to transform it. In fact, theory is seen as a tool to disrupt ideological constructs and expose hidden dynamics of socio-political domination (Bardzell \& Bardzell, 2013).

Critical philosophers of technology investigate the set of cultural values embedded in technology and analyse their relationship to aspects such as efficiency, productivity and its contribution to the progress of society. They do not consider technology as a mere tool, but rather as a form of organisation (Cooper, 2002), which can be defined as "scale, pace and pattern" (Swartz, 2016), where power sets the direction of production, distribution and final use (Mosco \& Wasko, 1988). In short, "technology and value are merely two sides of the same coin" (Carey, 1990: 250). This 
thought can be materialised in the question: what are 'ideologies' and 'politics' (Selwyn, 2019) of digital technologies in education?

Feenberg (2004: 8) explains the importance of a philosophical interest for the design of technologies:

Technological systems impose technical management on human beings. [...] It is the everyday lifeworld of a modern society, in which devices form a nearly total environment. In this environment, the individuals identify and pursue meanings. [...] How we configure and design cities, transportation systems, communication media, agriculture and industrial production is a political matter. And we are making more and more choices about health and knowledge in designing the technologies on which medicine and education increasingly rely.

According to Feenberg, a new technology is usually designed in a way to be integrated in a natural and social environment, where other technologies already exist. "Technical objects have a foot in two worlds. Their function joins a world of human intentions and a world of objective properties" (Feenberg, 2017: 136). However, the affordances that allow this integration are not separated from the uses that will follow. Uses and design, or said otherwise functional and aesthetic aspects, might seem two different sides of technologies, but they are rather interconnected. Design shapes usage and controls meanings.

Technology is a two-sided phenomenon: on the one hand the operator, on the other the object. Where both operator and object are human beings, technical action is an exercise of power. Where, further, society is organized around technology, technological power is the principle form of power in the society. It is realized through designs which narrow the range of interests and concerns that can be represented by the normal functioning of the technology and the institutions which depend on it (Feenberg, 2004: 2).

In Feenberg's reflections on the relationship between technology and society, we find a way that leads to the critical view beyond the utopian and dystopian considerations about technologies, while at the same time considers them not neutral. From this critical stance, we realise that the conception of technology as a neutral entity promotes a reductionist view of the relationship between man and technique. In fact, ignoring the context is a first step into ignoring power relations and forces that are constantly reshaping technology (Morozov, 2011).

In order to unveil the biases of technologies, Feenberg (2017) suggests that a process of redesign would allow the users to reform not only the technical sphere, but also the values that are embedded in it. A democratic process from below would open up technology to a wider range of interests and possible uses.

Some authors have taken this discussion to the field of education, arguing that making sense of contemporary education entails undertaking research on political and democratic dimensions (Biesta, 2010; Pischetola \& Heinsfeld, 2018) and dealing with macro-aspects that define pedagogical complexity (Dale et al., 2004; Davis \& Sumara, 2008), beyond a focus on learning efficiency (Buckingham, 2020; Selwyn, 2010). In fact, reductionism disengages the process of meaning-making from historical and contextual factors, objectives, values, ideologies, the beliefs and intentions that determine the presence and evolution of technologies in educational contexts. Technology-driven education happens to be "reductive, non-representative, unjust, and exploitative" (Selwyn, 2019: 15).

On the contrary, the scope of educational inquiry has to keep a broad interest on complex sociopolitical and cultural issues rising from the increasing presence of digital technologies at all levels of schooling and higher education. The basic assumption that arises from critical theory is that "the nature and form of any technology - pencil, gun, or learning analytics - is not set in stone" (Selwyn, 2019: 15) and change is possible. 
Research suggests that providing teachers with the opportunity to re-design curriculum materials and learning environments can be a fruitful strategy to learn and reflect upon digital technology meaningful adoption (Tondeur et al., 2019). Advanced educational technologies (Shadiev \& Yang, 2020) can be used for endless purposes - among them simulation, extended classroom practices, collaborative multimedia production, and multisensorial experiences (Covaci et al., 2018). When teachers find themselves in the position to relate subject contents, ICT and curriculum, they have the opportunity to discuss and reconsider their pedagogical and epistemic beliefs (Pischetola, 2020). Moreover, group work might reduce the feeling of insecurity that teachers experience when they need to plan activities with technologies (Tearle \& Golder, 2008; Tondeur 2020). Another important aspect is freedom to experiment and autonomy to create (Acosta Corporán et al., 2019). Educational technology designers should always take into account the need for teachers to define their own uses, related to individual motivations for using any technology (Ferdig, 2006; Pischetola \& Dirckinck-Holmfeld, 2020).

All together, these studies illustrate how teachers' perception and attitude to educational technology not only regard the technology itself, but also the pedagogical values and approaches that underpin their design. Critical theory, therefore, offers important theoretical tools to question the embedded values in digital technologies and to empower teachers through a process of redesign.

On the other hand, there are several difficulties emerging from the encounter between critical theory and (re)design. The aspiration to transform society through a wider democratisation of decisions about digital technologies interfaces, functions and features, for example, is a very complex commitment (Lindtner et al. 2016) which clashes with commercial interests and increasing datafication of society (Williamson et al., 2020b). Analysis of power relations contribute to expanding critical thinking, but they also need clear methodological pathways (Bardzell, 2018).

At this respect, Bardzell et al. (2012: 290) suggest that critical theory offers little support about how to "make things" concretely. In fact, its subversive, disruptive and "anti-method" character makes its hard to be operationalised in the design process. Moreover, the authors mention that critical theorists have "little to say about creative intention" (ibid.). Creativity is a critical component of any learning environment, as many scholars consider it as the most relevant $21^{\text {st }}$ century skills (Lin et al., 2020). It corresponds to the ability to produce original and useful work, which can be a product or an idea. ICT-mediated learning environments play a crucial role in promoting creativity skills (Shadiev et al., 2017), and therefore such an important element should not be overlooked. To address the pitfalls of critical theory, Bardzell (2018) proposes to engage with feminist utopianism, which presents over-arching participatory methods that could contribute to IT design practices. Bødker (2003) claims that questioning technology is an obligation for researchers and that this can be done through research-based participatory design. Working with people, groups, and organisations about specific settings, says the author, helps them realise that they have an alternative.

In the same line of thought, Mirra et al. (2018) argue for the need to emphasise criticality in media literacy studies and propose to retheorise critical studies in education through advances in post-structural, anticolonial, and feminist social analysis. They claim that the expansion of the theoretical frame can contribute to a "pedagogy of digital invention" (Mirra et al., 2018: 15), which is focused on equity, inclusion, and decision-making democratisation. The authors refer to connected learning (Ito et al., 2013) as a way of considering technologies not valuable in themselves but as new opportunities to increase access, participation, and justice (Garcia, 2014; Pischetola, 2011). Other scholars also mention imagination among the characteristics to be valued in humans, which will never be achieved by machine intelligence (Braga \& Logan, 2017; Hasse, 2019).

For the purpose of this paper - which is building a narrative that overcomes techno-solutionism in education - we consider these contributions very valuable. They try to place an emphasis on the 
recursive relationships among humans (teachers) and technologies (digital tools and environments), while keeping a critical eye towards motives, values, ideologies, hidden meanings and structures that define our contemporary society. Through these lenses, we understand that pedagogical adoption of technologies is not merely a technical issue, depending on teachers' skills and competencies, or even personal attitudes, but also a socioeconomic and political matter, which is concerned with the reasons why technologies are introduced and incorporated into existing pedagogies and educational settings.

In what follows, we provide an argument about how central commitment to critical pedagogy takes us to understanding technology pedagogical adoption and redesign as an ethical, epistemological, and ontological engagement.

\section{b. Feminist new materialism and the importance of agency}

According to Lindtner et al. (2016), a critique of the present has to be followed by a utopia of the future. This idea resonates in Bardzell's (2018) proposal to consider utopia not merely as vision the dream society - but rather as a cognitive act, that directs our imagination towards future intentions. Bardzell refers to feminism to undertake a revision of traditional utopianism. She affirms that the key problem of utopias - and we can think of techno-solutionism as one of them is that the imagined future is too detached from the present. The utopian imagination of grand explanatory theories fails in considering what the real mechanisms for change are. Feminist materialist studies recall a focus on the 'small' narratives, instead. They foresee the development of marginalised voices through qualitative and post-qualitative methods of inquiry, which centre around ethnography.

In this paper, we draw on material-semiotic post-humanism (Haraway, 1991) and material feminism (Barad, 2007; Bennett, 2010; Braidotti, 2013), to find insights for such an alternative imaginary for a post-pandemic future of technology in education. Important contributions come also from decolonial studies, which reframe the situated technological and socio-cultural processes from a non-Western perspective (Lindtner et al. 2016), and consider the material, discursive and collective relationships that emerge as "global assemblages" (Ong \& Collier, 2004). Colonialism has imposed "a competitive individualised subjectivity in education that continues to regard people, land and knowledge as property" (Murris, 2018: 6). A shift towards a relational ontology invites us to queer the binaries and thus reconfigure our identity (Barad, 2012).

At the crossroad of science and humanities, feminist new materialism explores the material processes and practices of worlding, based on a post-human focus on the matter. In a neomaterialist perspective, the fact that researchers consider human and technologies, social and technical, subject and object, body and mind as ontologically separate entities is a sign of anthropocentric thinking and a heritage from the dualistic view of Cartesian metaphysics (Hultin, 2019). Anthropocentrism, in fact, takes for granted humans as the starting point of any action, overemphasising language as opposed to materiality influence (Lenz Taguchi, 2011). Such belief relies on a dichotomous view of reality with a dominant thinking based on separateness (Ferrando 2020); as mind is separated from body with all that they could entail, human learning results from an enactment on "inert" things waiting to be interpreted.

In a post-anthropocentric worldview, the focus is on the embodiment and embeddedness of human imaginaries (Klumbyté et al., 2019), and realities emerge from the entanglement of human (educators) and non-human agents (digital tools and platforms).

Donna Haraway (2016) points out that in our post-human era the fusion of humanity and technology is ever more evident. The hybrid ontology of a cyborg (Haraway, 1991) shows that technologies have an agency, which emerges in unforeseeable and unpredictable ways. The material world co-creates the socio-cultural reality and transforms who we are in relation to it (Hasse, 2019). This does not mean that objects have the same kind or degree of intention in their 
doing (Taylor, 2019). Rather, we should see that people are always entangled with matter and environments and thus have agency by virtue of associations (Latour, 1994). This understanding of the existence of dynamic entanglements between humans and technologies is also known as relational materialism, as it has in its core relations which swaps extremes - such as mind and body or discourse and substance - and flatten out hierarchies between humans and matter (Lenz Taguchi, 2011).

This entanglement between humans and objects is described by Karen Barad (2007) as the 'intraaction' that occurs within a phenomenon.

Phenomena are constitutive of reality. Reality is composed not of things-inthemselves or things-behind-phenomena but of things-in-phenomena. The world is a dynamic process of intra-activity and materialization in the enactment of determinate causal structure with determinate boundaries, properties, meanings, and patterns of marks on bodies (Barad, 2007: 140).

Barad suggests that being (ontology) and knowing (epistemology) are inseparable, and this assumption brings about ethical consequences. In fact, if we cannot disentangle humans, matter, and environment, we need to acknowledge that words get materialised and encourage that material-discursive practices are followed by responsible actions. In Barad's words, we have to recognise that we are always interpreting and co-creating a phenomenon through "agential cuts" (Barad, 2007: 140).

As we can see, new materialism is an invitation to understand technology beyond determinism, solutionism and instrumentalism, and to recognise its agency, instead. If we look at the imaginaries of post-pandemic educational landscapes, what are the agential cuts that will frame the presence of digital technologies in teaching? What are digital technologies already doing to teaching and learning?

In educational literature about agency, we can see that the attribute of 'being able to act' concerns only teachers' and pupils' actions. In recent years, Biesta and collaborators have made the attempt to reframe teacher agency within the tradition of pragmatist philosophy and have considered it as the result of an ecological and emergent process (Biesta \& Tedder, 2007; Biesta et al., 2015). According to this perspective, agency is a critical response to a determined situation and its achievement depends upon individual efforts, available resources, and contextual factors (Biesta, 2010). In other words, agency is something that people do or engage with, more than something they have (Biesta et al., 2015).

Feminist new materialism can help us to rethink educational spaces as emergent intersections between vital and multiple materialities (Taylor, 2019), and to understand the material relationships and entanglements that appear along the way. Agential cuts, for example, can be used as lenses to interpret contemporary processes of education digitalisation (Pischetola et al., 2020), as they contribute to make visible "digital doings" (Alirezabeigi et al., 2020: 197), or more generally, to unveil the "invisible pedagogy" (Bernstein 2000) made of relations, meanings, and power structures. Following such disruptive unfoldment of invisible processes and structures, it is needed to address problems such as marginalisation and inequality, and work in a perspective of care (Puig de la Bellacasa, 2011) and responsibility - or "response-ability", as Haraway (2016: 35) names it. Based on situated knowledges (Haraway, 1988), feminist and decolonial ethics calls for a paradigm shift, "from universalism to perspectivism, from multiculturalism to pluralism and diversity (...), from technology to eco-technology, (...) from individuality to relationality" (Ferrando, 2020: 8). Haraway (2016: 3) explains the importance of "staying with the trouble", which entails rejecting both "a faith in technofixes" and the defeated attitude of "there's no sense in trying to make anything better".

Ethics manifests itself in our way of living and exploring the counter-hegemonic potential of imagination and alternative discursive-material practices. Looking beyond dualisms, we can de- 
naturalise the dialectical separation categorisation typical of Western tradition, and see that in all reconfiguring changes of power, there is occasionally space for empowering opportunities (Mansell, 2017) and alternative worldly enactments (Thiele, 2014). In this view, thinking-making the imaginary of the future education is an exercise of ethics and responsibility.

\section{Conclusion}

The attempt of this article has been to sketch out some concerns arising from a critical-materialist view of digital technologies in education. We have addressed technological determinism, technosolutionism, and instrumentalism, as spread arguments for the increasing presence of digital tools, platforms and data-driven practices in educational settings worldwide. By pointing out these trends, we have tried to use theory as a worldmaking practice and thus identify some important aspects of future educational transformation that are worth of attention.

First, we need to think disruptively about digital technologies in education, that is, not allowing traditional ways of linear thinking to drive our imaginary. Technological determinism, technosolutionism, instrumentalism, and any other form of causal expression of the relationship between technology and education are simplistic and reductive ways of conceiving the future of schools and university. Critical theory has provided us with a focus on human activity as interconnected with social and situated practices. The emphasis is on recursive relations that allow educational researchers and practitioners to take into account the considerable complexity of digital technologies pedagogical adoption.

Second, a focus on multiplicity, diversity and non-binary categories will support our imaginary in terms of empowerment and inclusion. At this respect, new materialism brings about a new focus on relational ontology, which adds to the critical theoretical framework the agentic element. From this point of view, teachers' actions are coupled to digital technologies in the construction of the environment. In educational research, this means to study sociotechnical infrastructure, computational materials, and the consequences of the presence of digital technologies on learning outcomes and individual growth.

These theoretical perspectives rely on two main drivers of change: connected/networked learning and situated knowledges. They give value to the small narratives and small utopias, from which they suggest taking concrete steps towards a re-design and re-interpretation of edtech. We need both views in order to adopt technologies in education in meaningful, productive and creative ways. A critical-materialist perspective can help us explore future imaginaries emerging from the entanglements between human and technologies in educational settings. This entails focusing on embedded values and interests that populate the field of technology and education, questioning the meaning of 'learning' with machines, and ultimately reflecting on the role of educators not only as an answer to the needs imposed by the market, but for a deeper meaning of citizenship and societal change. 


\section{Disclosure statement}

No potential conflict of interest was reported by the author.

\section{References}

Acosta Corporán, R., Martín-García, A. V. \& Hernández Martín, A. (2019). Uso de las Metodologías de Aprendizaje Colaborativo con TIC: Un análisis desde las creencias del profesorado. Digital Education Review, 35, 309-323.

Aldunate, R.; Nussbaum, M. (2013). Teacher adoption of technology. Computers in Human Behavior, 29 (3), 519-524. DOI: $10.1016 / j . c h b .2012 .10 .017$

Alexander, B., Ashford-Rowe, K., Barajas-Murphy, N., Dobbin, G., Knott, J., McCormack, M., Pomerantz, J., Seilhamer, R. \& Weber, N. (2019) EDUCAUSE Horizon Report: 2019 Higher Education Edition. Louisville, CO: EDUCAUSE.

Alirezabeigi, S.; Masschelein, J.; Decuypere, M. (2020) Investigating digital doings through breakdowns: a sociomaterial ethnography of a Bring Your Own Device school. Learning, Media and Technology, 45 (2), 193-207. Doi: 10.1080/17439884.2020.1727501

Andrade, M.; Pischetola, M. (2016). O discurso de ódio nas mídias sociais: a diferença como letramento midiático e informacional na aprendizagem. Revista e-curriculum, 14 (4), 1377- 1394.

Balanskat, A., Blamire, R., and Kefala, S. (2006). The ICT Impact Report: A Review of Studies of ICT Impact on Schools in Europe. European Schoolnet (online), Brussels, Belgium.

Balsamo, A. (2011). Designing culture. The technological imagination at work. Durha, NC: Duke press.

Bannell, R. (2019). Out of our Minds? Learning beyond the brain. In: Leporace, C., Bannell, R., Rodrigues, E., Santos, E. et al. (Eds). A Mente Humana para Além do Cérebro. Coimbra: Universidade de Coimbra.

Barad, K. (2007). Meeting the universe halfway: Quantum physics and the entanglement of matter and meaning. Durham, NC: Duke University Press.

Barad, K. (2012). Intra-actions: An interview with Karen Barad by Adam Kleinman. Mousse, 34, 76-81.

Bardzell, S. (2018). Utopias of Participation: Feminism, Design, and the Futures. ACM Transactions on Computer-Human Interaction, 25 (1), Article 6.

Bardzell, S., Bardzell, J., Forlizzi, J., Zimmerman, J., and Antanitis, J. (2012). Critical design and critical theory: The challenge of designing for provocation. Proc. of DIS'12. ACM Press.

Bardzell, J. \& Bardzell, S. (2013). What is "Critical" about Critical Design? Proceedings of the CHI 2013: Changing Perspectives, Paris, France.

Barnett, R.; Bengsten, S. (2017). Confronting the Dark Side of Higher Education. Journal of Philosophy of Education, 51 (1), 114-131.

BECTA - British Educational Communications and Technology Agency. (2004). A review of the research literature on barriers to the uptake of ICT by teachers. Retrieved December 13, 2019, from http:// dera.ioe.ac.uk/1603/1/becta_2004_barrierstouptake_litrev.pdf

Bennett, J. (2010). Vibrant matter: A political ecology of things. Duke University Press

Bernstein, B. (2000). Pedagogy, Symbolic Control and Identity: Theory, Research, Critique. Revised edition. Oxford: Rowman.

Biesta, G. (2010). Why "What Works" Still Won't Work: From Evidence-Based Education to Value-Based Education', Stud. Philos. Educ., 29 (5), 491-503. DOI: 10.1007/s11217-010-9191-x.

Biesta, G. \& Tedder, M. (2007). Agency and learning in the lifecourse: Towards an ecological perspective. Stud. Educ. Adults, 39 (2), 132-149. DOI: 10.1080/02660830.2007.11661545. 
Biesta, G., Priestley M., \& Robinson S. (2015). The role of beliefs in teacher agency. Teachers and Teaching, 21(6), 624-640, DOI: 10.1080/13540602.2015.1044325.

Bingimlas, K. A. (2009). Barriers to the successful integration of ICT in teaching and learning environments: A review of the literature. Eurasia journal of mathematics, science \& technology education, 5 (3), 235-245.

Braga, A. \& Logan, R. (2017). The Emperor of Strong AI Has No Clothes: Limits to Artificial Intelligence. Information, 8, 156-177. DOI: 10.3390/info8040156

Braidotti, R. (2013). The posthuman. Cambridge, UK: Polity Press

Brown, M., McCormack, M., Reeves, R., Brooks, D., \& Grajek, S., (2020) 2020 EDUCAUSE Horizon Report, Teaching and Learning Edition. Louisville, CO: EDUCAUSE.

Bødker, S. (2003). A for alternatives. Scandinavian Journal of Information Systems, 15 (2003), 87-89.

Buckingham, D. (2020). Epilogue: Rethinking digital literacy: Media education in the age of digital capitalism. Digital Education Review, 37 (monographic), 230-239.

Carey, J. W. (1990). Technology as a totem for culture: And a defense of the oral tradition. American Journalism, 7, 242-251.

Caena, F. and Redecker, C. (2019). Aligning teacher competence frameworks to 21st century challenges: The case for the European Digital Competence Framework for Educators (DIGCOMPEDU), European Journal of Education, 54 (3), 356-369.

Çoban, B. (ed.) (2016). Social Media and Social Movements: The Transformation of Communication Patterns. Lanham: Lexington Books.

Coeckelbergh, M. (2011). Human development or human enhancement? A methodological reflection on capabilities and the evaluation of information technologies. Ethics Inf Technol, 13, 81-92. DOI: $10.1007 /$ s10676-010-9231-9

Cooper, S. (2002). Technoculture and Critical Theory. In the service of the machine? London and New York: Routledge.

Covaci, A., Zou, L., Tal, I., Mntean, G., Ghinea, G. (2018). Is Multimedia Multisensorial? - A Review of Mulsemedia Systems. ACM Computing Surveys, 51 (5), Article 91.

Creanor, L. \& Walker, S. (2012). Learning Technology in Context: A Case for the Sociotechnical Interaction Framework as an Analytical Lens for Networked Learning Research. In: L. Dirckinck-Holmfeld, V. Hodgson, and D. McConnell, (eds.). Exploring the Theory, Pedagogy and Practice of Networked Learning, New York, NY: Springer, 173-187.

Cuban L. (2002). Oversold and Underused: Computers in the Classroom. Harvard University Press, Cambridge, MA.

Dafoe, A. (2015). On Technological Determinism: A Typology, Scope Conditions, and a Mechanism. Science, Technology, \& Human Values, 40 (6), 1047-1076.

Dale R., Robertson S. \& Shortis T. (2004) You can't not go with the technological flow, can you? Journal of Computer Assisted Learning, 20, 456-470.

Dall'Alba, G. (2009). Learning Professional Ways of Being: Ambiguities of becoming. Educational Philosophy and Theory, $41(1), 34-45$.

Davis, F. (1993). User acceptance of information technology: System characteristics, user perceptions, and behavioural impacts. International Journal of Man Machine Studies, 38, 475-487.

Davis, B. \& Sumara, D. (2008). Complexity as a theory of education. Curriculum Inquiry, 5 (2), 33-44.

Drent, M. \& Meelissen, M. (2008). Which factors obstruct or stimulate teacher educators to use ICT innovatively? Computers \& Education, 51 (1), 187-199. DOI: 10.1016/j.compedu.2007.05.001

Dusek, V. (2006). Philosophy of Technology: an Introduction. Malden, MA: Blackwell Publishing. 
Embretson, S. E. (2004). Measuring Human Intelligence with Artificial Intelligence: Adaptive item generation. In: R. J. Sternberg \& J. Pretz (eds.). Cognition and intelligence. New York: Cambridge University Press, 251-267.

Feenberg, A. (2002). Transforming technology: A critical theory revisited. Oxford, UK: Oxford University Press.

Feenberg, A. (2003). Modernity Theory and Technology Studies: Reflections on Bridging the Gap. In: Misa, T., Brey, P. \& Feenberg, A. (Eds.). Modernity and Technology. Cambridge, MA: MIT Press.

Feenberg, A. (2004). Heidegger and Marcuse: The Catastrophe and Redemption of History. New York and London: Routledge.

Feenberg, A. (2017). Technosystem: The Social Life of Reason. Cambridge, MA: Harvard University Press.

Feenberg, A. (2019). The internet as network, world, co-construction, and mode of governance. The Information Society, 35 (4), 229-243.

Fenwick T.; Edwards, R. (2014). Networks of knowledge, matters of learning, and criticality in higher education. Higher Education, 67 (1), 35-50.

Ferdig, R.E., Baumgartner, E., Hartshorne, R., Kaplan-Rakowski, R. \& Mouza, C. (Eds). (2020). Teaching, Technology, and Teacher Education During the COVID-19 Pandemic: Stories from the Field. Association for the Advancement of Computing in Education (AACE). Retrieved June 15, 2020 from https://www.learntechlib.org/p/216903/.

Ferguson, R., Coughlan, T., Egelandsdal, K., Gaved, M., Herodotou, C., Hillaire, G., Jones, D., Jowers, I., Kukulska-Hulme, A., McAndrew, P., Misiejuk, K., Ness, I. J., Rienties, B., Scanlon, E., Sharples, M., Wasson, B., Weller, M. and Whitelock, D. (2019). Innovating Pedagogy 2019: Open University Innovation Report 7. Milton Keynes: The Open University.

Ferrando, F. (2020). Posthuman Feminist Ethics: Unveiling Ontological Radical Healing. In: Thomsen, M. R., Wamberg, J. (eds.), Bloomsbury Handbook of Posthumanism, Bloomsbury: London et al.

Ferreira, G. \& Lemgruber, M. (2018). Metáforas Fundamentais da Tecnologia Educacional. Educação em Foco, 23 (1), 15-38. DOI: 10.22195/2447-524620182320012

Ferreira, G. M.; Rosado A., Carvalho J. (eds.) (2017). Education and Technology: Critical Approaches. Rio de Janeiro: UNESA.

Frau-Meigs, D., O’Neill, B., Soriani, A, Tomé, V. (2017). Digital Citizenship Education, vol. 1. Strasbourg: Council of Europe Publishing.

Garcia, A. (Ed.). (2014). Teaching in the connected learning classroom. Irvine, CA: Digital Media and Learning Hub

Gomes, G.; Torrens, E. W.; Cunha, P. R. (2012). Motivação e Resistência ao Uso da Tecnologia da Informação: Um Estudo Entre Professores. Administração: Ensino e Pesquisa, 13 (2), 301-324.

Goodwin, A. Lin; Low, Ee Ling; Ng, Pak Tee; Yeung, A. S.; Cai, Li (2015). Enhancing Playful Teachers' Perception of the Importance of ICT Use in the Classroom: The Role of Risk Taking as a Mediator. Australian Journal of Teacher Education, 40 (4), 1-19.

Grimaldi, E. \& Ball, S. (2019): The blended learner: digitalisation and regulated freedom - neoliberalism in the classroom, Journal of Education Policy, DOI: 10.1080/02680939.2019.1704066

Haraway, D. (1988). Situated Knowledges: The Science Question in Feminism and the Privilege of Partial Perspective. Feminist Studies, 14 (3), 575-599. DOI: https://doi.org/10.2307/3178066

Haraway, D. (1991). A Cyborg Manifesto: Science, Technology, and Socialist-Feminism in the Late Twentieth Century. In: Simians, Cyborgs, and Women: The Reinvention of Nature. New York: Routledge.

Haraway, D. (2016). Staying with the trouble: Making kin in the Chthulucene. London: Duke University Press.

Hasse, C. (2019). Posthuman learning: AI from novice to expert? AI \& SOCIETY, 34, 355-364. DOI: https:// doi.org/10.1007/s00146-018-0854-4.

Hayes, S. (2018). Invisible labour: Do we need to reoccupy student engagement policy? Learning and Teaching $11(1), 19-34$. 
Heinsfeld, B. D.; Pischetola, M. (2019). Discourse on technologies in public policies on education. Educação \& Pesquisa, 45. DOI: 10.1590/s1678-4634201945205167

Hodges, C., Moore, S., Lockee, B., Trust, T., \& Bond, A. (2020). The difference between emergency remote teaching and online learning. EDUCAUSE Review.

Howard, S.; Gigliotti, A. (2016). Having a go: Looking at teachers' experience of risk-taking in technology integration. Education and Information Technologies, 21, 1351-1366. DOI: 10.1007/ s10639-015-9386-4.

Hitty, U. (Ed.) (2002). State-of-Art of Enterprise Education in Europe - Results from the Entredu project. Leonardo da Vinci - programme of the European Commission, Turku.

Hultin, L. (2019). On becoming a sociomaterial researcher: Exploring epistemological practices grounded in a relational, performative ontology. Information and Organization 29, 91-104.

Ito, M., Gutierrez, K., Livingstone, S., Penuel, B., Rhodes, J., Salen, K., Watkins, C. (2013). Connected learning: An agenda for research and design. Irvine, CA: Digital Media and Learning Research Hub.

Jandrić and Hayes (2020), Postdigital We-Learn. Studies in Philosophy and Education. DOI: https://doi.org/ $10.1007 / \mathrm{s} 11217-020-09711-2$

Jamieson-Proctor, R. M.; Burnett, P. C.; Finger, G.\& Watson, G. (2006) ICT integration and teachers' confidence in using ICT for teaching and learning in Queensland state schools. Australasian Journal of Educational Technology, 22 (4), 511-530.

Klumbyté, G., Draude, C. \& Britton, L. (2019). Re-Imagining HCI: New Materialist Philosophy and Figurations as Tool for Design. Workshop "Standing on the Shoulders of Giants: Exploring the Intersection of Philosophy and HCI", ACM CHI Conference on Human Factors in Computing Systems, Glasgow, UK.

Kocsev, M., Hansen, N., Hollow, D. \& Pischetola, M. (2009). Innovative Learning in Ethiopia. Addis Ababa: ECBP working paper.

Korte, W. B. \& Hüsing, T. (2007). Benchmarking access and use of ICT in European schools 2006: Results from Head Teacher and A Classroom Teacher Surveys in 27 European countries. eLearning Papers, 2 (1), $1-6$.

Kukulska-Hulme, A., Beirne, E., Conole, G., Costello, E., Coughlan, T., Ferguson, R., FitzGerald, E., Gaved, M., Herodotou, C., Holmes, W., Mac Lochlainn, C., Nic Giollamhichil, M., Rienties, B., Sargent, J., Scanlon, E., Sharples, M. and Whitelock, D. (2020). Innovating Pedagogy 2020: Open University Innovation Report 8. Milton Keynes: The Open University.

Kurzweil, R. (2006). Reinventing Humanity: The Future of Machine-Human Intelligence. The Futurist, 40 (2), $39-46$.

Latour, B. (1994). On Technical Mediation. Common Knowledge, 3 (2), 29-64.

Lawrence, J. E. \& Tar, U. A. (2018) Factors that influence teachers' adoption and integration of ICT in teaching/ learning process, Educational Media International, 55 (1), 79-105, DOI: $10.1080 / 09523987.2018 .1439712$

Lenz Taguchi, H. (2011). Investigating Learning, Participation and Becoming in Early Childhood Practices with a Relational Materialist Approach. Global Studies of Childhood, 1 (1). DOI 10.2304/gsch.2011.1.1.36

Lin, L., Shadiev, R., Hwang, W., \& Shen, S. (2020). From knowledge and skills to digital works: An application of design thinking in the information technology course, Thinking Skills and Creativity, 36. DOI: $10.1016 /$ j.tsc. 2020.100646 .

Lindtner, S., Bardzell, S., Bardzell, J. (2016). Reconstituting the Utopian Vision of Making: HCI After Technosolutionism. Proceedings of the CHI Conference 2016, San Jose, CA, USA.

Mangiatordi, A., Pischetola, M. (2010). Sustainable Innovation Strategies in Education: OLPC case studies in Ethiopia and Uruguay. In: Lytras M. D. et al. (eds). Organizational, Business, and Technological Aspects of the Knowledge Society, Communications in Computer and Information Science. Springer Berlin Heidelberg, 94-104. 
Mansell, R. (2017). Imaginaries of the Digital: Ambiguity, Power and the Question of Agency. Communiquer. Revue de Communication Sociale et Publique, 20, 40-48. DOI: 10.4000/communiquer.2261

McCarthy, J. (1959). Programs with Common Sense. Mechanisation of Thought Processes, Proceedings of the Symposium of the National Physics Laboratory, 77-84, London UK.

Milan, S. (2020). Techno-solutionism and the standard human in the making of the COVID-19 pandemic. Big Data \& Society, 1-7 DOI: 10.1177/2053951720966781

Miranda, L. V. T., Pischetola, M. (2020). Teaching as the emergent event of an ecological process: Complexity and choices in one-to-one programmes. Explorations in Media Ecology, 19 (4), 503-519. DOI: 10.1386/eme_00065_1

Mirra, N.; Morrell, E.; \& Filipiak, D. (2018). From Digital Consumption to Digital Invention: Toward a New Critical Theory and Practice of Multiliteracies, Theory Into Practice, 57 (1), 12-19, DOI: 10.1080/00405841.2017.1390336

Morozov, E. (2011). The Net Delusion: The Dark Side of Internet Freedom. New York: Public Affairs.

Morozov, E. (2014). The rise of data and the death of politics. The Guardian, 20 Jul. Retrieved November 24, 2020 from https://www.theguardian.com/technology/2014/jul/20/rise-of-data-death-of-politicsevgeny-morozov-algorithmic-regulation.

Mosco, V., \& Wasko, J. (Eds.). (1988). The political economy of information. Madison: University of Wisconsin Press.

Murris, K. (2018). Posthuman Child and the Diffractive Teacher: Decolonizing the Nature/Culture Binary. In: A. Cutter-Mackenzie et al. (eds.), Research Handbook on Childhoodnature, Springer International Handbooks of Education, DOI: https://doi.org/10.1007/978-3-319-51949-4_7-2

Oliver, M. (2011). Technological determinism in educational technology research: some alternative ways of thinking about the relationship between learning and technology. Journal of Computer Assisted Learning, 27 (5), 373-384. DOI: 10.1111/j.1365-2729.2011.00406.x

Ong, A. \& Collier, S. J. (eds.) (2004). Global Assemblages: Technology, Politics, and Ethics as An- thropological Problems. Wiley-Blackwell.

Peck, J. \& Tickell, A. (2002). Neoliberalizing Space. Antipode, https://doi.org/10.1111/1467-8330.00247

Peixoto, J. (2015). Relações entre sujeitos sociais e objetos técnicos: uma reflexão necessária para investigar os processos educativos mediados por tecnologias. Revista Brasileira de Educação, 29 (61). DOI: https://doi.org/10.1590/S1413-24782015206103.

Peters, M.A., P. Jandrić, and S. Hayes (2019). The curious promise of educationalising technological unemployment: What can places of learning really do about the future of work? Educational Philosophy and Theory 51 (3): 242-254. https://doi.org/10.1080/00131857.2018.1439376.

Philip, T. M. \& Garcia, A. (2013). The Importance of Still Teaching the iGeneration: New Technologies and the Centrality of Pedagogy. Harvard Educational Review, 83 (2), 300-319.

Pischetola, M. (2014). Teaching with Laptops: A Critical Assessment of One-to-one Technologies. In: M. Stocchetti (ed.) Media and Education in the Digital Age. Concepts, Assessments, Subversions, pp. 203-214. Frankurt: Peter Lang.

Pischetola, M. (2011). Educazione e divario digitale. Idee per il capacity building. Milano: Unicopli.

Pischetola, M. (2019). Teachers and technologies in Brazilian schools: a study from the perspective of media ecology. Italian Journal of Sociology ofEducation, 11 (2), 411-427. Doi: https://doi.org/10.14658/ pupj-ijse-2019-2-20.

Pischetola, M. (2020). Exploring the relationship between in-service teachers' beliefs and technology adoption in Brazilian primary schools. International Journal of Technology and Design Education, DOI 10.1007/ s10798-020-09610-0

Pischetola, M. (2021). Teaching Novice Teachers to Enhance Learning in the Hybrid University. Postdigital Science and Education Journal. Doi: https://doi.org/10.1007/s42438-021-00257-1 
Pischetola, M. \& Dirckinck-Holmfeld, L. (2020). Enactivism and Digital Learning Platforms. Proceedings of the Networked Learning Conference.

Pischetola, M., Heinsfeld, B. D. (2018). Technologies and teacher's motivational style: A research study in Brazilian public schools. Journal of Educational, Cultural and Psychological Studies 17, 163-177. DOI 10.1386/cjmc.9.2.253_1

Pischetola, M.; \& Miranda, L. V. T. (2019). A sala de aula como ecossistema. Tecnologias, complexidade e novos olhares para a educação. Rio de Janeiro: Editora PUC-Rio.

Pischetola, M.; Miranda, L.V.T.; Albuquerque, P. (2020). Sociomaterialidade e digitalização da educação: reformulando a prática e a pesquisa em uma perspectiva pós-humana. In: Bannell, R., I., Mizrahi, M., Ferreira, G. M. Deseducando a educação: mentes, materialidades e metáforas. Rio de Janeiro: Editora PUC-Rio.

Postman, N. (1992). Technopoly: The surrender of culture to technology. New York: First Vintage Books Edition.

Priestley, M. (2011). Whatever happened to curriculum theory? Critical realism and curriculum change', Pedagogy Culture \& Society, 19 (2), 221-237. DOI: 10.1080/14681366.2011.582258.

Puig de la Bellacasa, M. (2011). Matters of care in technoscience: Assembling neglected things, Social Studies of Science, 41 (1), 85-106. DOI: 10.1177/0306312710380301

Ransom, T. G. \& Gallagher, S. (2020). Institutions and other things: critical hermeneutics, postphenomenology and material engagement theory. AI \& Society, 1-8. DOI: 10.1007/s00146-020-00987-z

Sancho-Gil, J. M., Rivera-Vargas, P. \& Miño-Puigcercós, R. (2019): Moving beyond the predictable failure of EdTech initiatives. Learning, Media and Technology, 45 (1), 61-75. DOI: $10.1080 / 17439884.2019 .1666873$

Schoepp, K. (2005). Barriers to technology integration in a technology-rich environment. Learning and Teaching in Higher Education: Gulf Perspectives, 2 (1), 1-24.

Seikkula-Leino, J.; Ruskovaara, El; Ikavalko, M.; Mattila, J.; Rytkola, T. (2010). Promoting entrepreneurship education: the role of the teacher? Education + Training, 52 (2), 117-127. DOI: $10.1108 / 00400911011027716$

Selwyn, N. (2010). Looking beyond learning: notes towards the critical study of educational technology. Journal of Computer Assisted Learning, 26 (1), 65-73, DOI: 10.1111/j.1365-2729.2009.00338.x

Selwyn, N. (2017). Education and technology: critical questions. In: Ferreira, G. M.; Rosado A., Carvalho J. (eds.). Education and Technology: Critical Approaches. Rio de Janeiro: UNESA.

Selwyn, N. (2019). Should Robots Replace Teachers?: AI and the Future of Education. Cambridge, UK: Polity Press.

Selwyn, N., Hillman, T., Eynon, R., Ferreira, G., Knox, J., Macgilchrist, F. \& Sancho-Gil, J. M. (2019): What's next for Ed-Tech? Critical hopes and concerns for the 2020s, Learning, Media and Technology, DOI: 10.1080/17439884.2020.1694945

Selwyn, N., (2020). Digital Education in the Aftermath of COVID-19: Critical Concerns and Hopes. In: Selwyn, N., Macgilchrist, F., Williamson, B. Digital Education after COVID-19. TECHLASH - issue \#0

Selwyn, N., Hillman, T., Eynon, R., Ferreira, G., Knox, J., Macgilchrist, F. \& Sancho-Gil, J. M. (2020) What's next for Ed-Tech? Critical hopes and concerns for the 2020s. Learning, Media and Technology, 45 (1), 1-6, DOI: $10.1080 / 17439884.2020 .1694945$

Shadiev, R., Hwang, W.Y., Huang, Y. M., \& Liu, T. Y. (2017). Facilitating application of language skills in authentic environments with a mobile learning system. Journal of Computer Assisted Learning, 34 (1), 42-52. DOI: $10.1111 /$ jcal.12212

Silva, E., Loureiro, M. J. \& Pischetola, M. (2019) Competências digitais de professores do estado do Paraná (Brasil). Eduser-Revista de Educação, 11 (1), 61-75.

Singh, T. K. R. \& Chan, S. (2014). Teacher Readiness on ICT Integration in Teaching-Learning: a Malaysian Case Study. International Journal of Asian Social Science, 4 (7), 874-885. 
Shadiev, R. \& Yang, M. (2020). Review of Studies on Technology-Enhanced Language Learning and Teaching. Sustainability, 12(2), 524. DOI: 10.3390/su12020524

Shane, S. and Venkataraman, S. (2000). The promise of entrepreneurship as a field of research. Academy of Management Review, 25 (1), 217-26.

Smith, B. (2019). The Promise of Artificial Intelligence: Reckoning and Judgment. Boston: MIT Press.

Smith, M. \& Marx, L. (1994). Does Technology Drive History? The Dilemma of Technological Determinism. Cambridge MA and London: MIT Press.

Somekh B. (2008) Factors Affecting Teachers' Pedagogical Adoption of ICT. In: Voogt J., Knezek G. (eds) International Handbook of Information Technology in Primary and Secondary Education. Springer International Handbook of Information Technology in Primary and Secondary Education, vol 20. Springer, Boston, MA. DOI: 10.1007/978-0-387-73315-9_27

Swartz, J. (2016). Communication and curation: Embodied meaning and praxis (Doctoral dis- sertation). Eugene: University of Oregon.

Taylor, C. A. (2019), Diffracting the Curriculum: Putting "New" Material Feminism to Work to Reconfigure Knowledge-Making Practices in Undergraduate Higher Education", Theory and Method in Higher Education Research, 5, 37-52. DOI: 10.1108/S2056-375220190000005004

Tearle, P. \& Golder, G. (2008). The use of ICT in the teaching and learning of physical education in compulsory education: how do we prepare the workforce of the future?, European Journal of Teacher Education, 31 (1), 55-72, DOI: 10.1080/02619760701845016

Teräs, M., Suoranta, J., Teräs H., Curcher, M. (2020). Post-Covid-19 Education and Education Technology 'Solutionism': a Seller's Market, Postdigital Science and Education, 2 (3), 863-878. DOI: 10.1007/ s42438-020-00164-x.

Thiele, K. (2014). Ethos of Diffraction: New Paradigms for a (Post)humanist Ethics, Parallax, 20 (3), 202-216, DOI: $10.1080 / 13534645.2014 .927627$

Tondeur, J. (2020). Teachers' pedagogical beliefs and technology use. In M. A. Peters (Ed.), Encyclopedia of teacher education. Springer Nature Singapore Pte Ltd. https://doi. org/ 10.1007/978-981-13-1179-6_111-1.

Tondeur, J., Scherer, R., Baran, E., Siddiq, F., Valtonen, T., \& Sointu, E. (2019). Teacher educators as gatekeepers: Preparing the next generation of teachers for technology integration in education. British Educational Research Association, 50 (3), 1189-1209. https://doi.org/10.1111/bjet.12748.

Watson, G. (2006). Technology professional development: Long-term effects on teacher self-efficacy. Journal of Technology and Teacher Education, 14 (1), 151-166.

Williamson, B. (2019). New power networks in educational technology. Learning, Media and Technology, 44 (4), 395-398, DOI: 10.1080/17439884.2019.1672724

Williamson, B. (2020). Making markets through digital platforms: Pearson, edu-business, and the (e)valuation of higher education. Critical Studies in Education, 62 (1), 50-66, DOI: $10.1080 / 17508487.2020 .1737556$

Williamson, B; Eynon, R. \& Potter, J. (2020). Pandemic politics, pedagogies and practices: digital technologies and distance education during the coronavirus emergency. Learning, Media and Technology, 45 (2), 107-114, DOI: $10.1080 / 17439884.2020 .1761641$

Williamson, B., Bayne, S. \& Shay, S. (2020b). The datafication of teaching in Higher Education: critical issues and perspectives. Teaching in Higher Education, 25 (4), 351-365.

Williamson, B. \& Hogan, A. (2020). Commercialisation and privatization in/of education in the context of Covid-19. London: Education International. 